\title{
Characterisation of cultivation of the human cell line AGE1.HN.AAT
}

\author{
Eva Schräder ${ }^{1 *}$, Sebastian Scholz ${ }^{1}$, Jens Niklas ${ }^{5}$, Alexander Rath², Oscar Platas Barradas ${ }^{3}$, Uwe Jandt ${ }^{3}$, Volker Sandig ${ }^{5}$ \\ , Thomas Rose ${ }^{5}$, Ralf Pörtner ${ }^{3}$, Udo Reichl ${ }^{2}$, An-Ping Zeng ${ }^{3}$, Elmar Heinzle ${ }^{4}$, Thomas Noll ${ }^{1}$ \\ From 22nd European Society for Animal Cell Technology (ESACT) Meeting on Cell Based Technologies \\ Vienna, Austria. 15-18 May 2011
}

\section{Background}

Human cell lines are an interesting alternative to $\mathrm{CHO}$ cells for the production of recombinant proteins and monoclonal antibodies, because of their ability to produce genuine human posttranslational modifications. The human cell line AGE1.HN.AAT (ProBioGen, Berlin, Germany), that originated from human neural precursor tissue, has been adapted to serum-free conditions and cultivated in many different systems. Here we present our results using this cell line in a scale-up of batch cultivation from $50 \mathrm{~mL}$ vented polypropylene tube on a shaking platform, polycarbonate shakeflask (cultivation volume from $50 \mathrm{~mL}$ up to $300 \mathrm{~mL}$ ), a 2 L-glass vessel stirred tank reactor and a $20 \mathrm{~L}$-stainless steel stirred tank reactor (both Sartorius Stedim, Goettingen, Germany).

\section{Materials and methods}

Cultivations were performed with chemically-defined and animal-component-free media 42-MAX-UB (Teutocell, Bielefeld, Germany). Batch-cultivations were performed in $50 \mathrm{~mL}$-bioreactor tubes (TPP, Switzerland) shakeflasks (Corning Life Sciences, Netherlands), 2 Lglass vessel and $20 \mathrm{~L}$-stainless steel vessel (both Sartorius-Stedim, Germany). Chemostat-cultivation was done in 0.5 L-bioreactor (DASGIP, Juelich, Germany) with a media exchange rate of $7 \mathrm{~mL} / \mathrm{h}$. As a further cultivation system a dialysis-reactor (Bioengineering, Wald, Switzerland) was established, with a $1.3 \mathrm{~L}$ cell-containing inner chamber and a $4 \mathrm{~L}$ media reservoir in the outer chamber, separated by a semipermeable dialysis membrane.

* Correspondence: esc@zellkult.techfak.uni-bielefeld.de

'Institute for Cell Culture Technology, University of Bielefeld, Germany

Full list of author information is available at the end of the article

\section{Results}

Proliferation in controlled and uncontrolled systems

The AGE1.HN.AAT cells show similar growth in different unregulated vessels and culture volumes. The used systems ranged from $50 \mathrm{~mL}$-bioreactor tubes with a culture volume of up to $18 \mathrm{~mL}, 125 \mathrm{~mL}$-shakeflasks with a culture volume of up to $50 \mathrm{~mL}$ - to $250 \mathrm{~mL}$-shakeflasks, in which a culture volume of $100 \mathrm{~mL}$ can be used (Results shown in figure 1a).

Cultivation in $2 \mathrm{~L}$-glass vessel is as well feasible for batch process as well as preculture for $20 \mathrm{~L}$-vessel. Cultivation at a $20 \mathrm{~L}$-scale resulted in delayed cell growth but did not affect the final cell concentration (refer to figure 1b). AGE1.HN.AAT cells show a strong growthcoupled productivity as shown in figure 1c.

No difference between $2 \mathrm{~L}$ - and $20 \mathrm{~L}$-vessel concerning spec. productivity and spec. growth rate were observed. A scale-up of cultivation-volume in batch process is definitely possible.

\section{Cultivations with other systems}

Cultivation of AGE1.HN.AAT cells in dialysis-reactor is also possible and batch cultivation without mediaexchange in the outer chamber showed maximum cell density up to $1.6 \mathrm{E} 7$ viable cells per milliliter in the inner chamber after eight days of cultivation.

Chemostat-cultivation in $0.5 \mathrm{~L}$-glass vessel shows constant cell density at $2.5 \mathrm{E} 6$ cells $/ \mathrm{mL}$ for more than 14 days.

\section{Conclusions}

Cultivation of AGE1.HN cell line is possible in different regulated and unregulated systems and at different scales. Cell specific productivity and titer of the AGE1. HN.AAT producer cell line depend mainly on cell growth. The cells are easily scalable from 2 to $20 \mathrm{~L}$ 

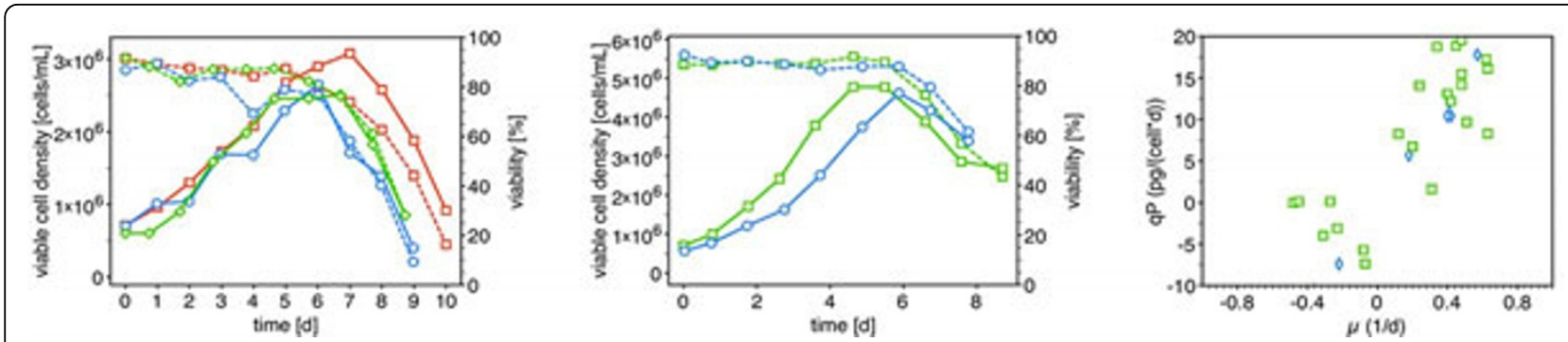

Figure 11.1 (left): viable cell density and viability during shake flask batch-cultivation. open squares: bioreactor tube, open circles: $125 \mathrm{~mL}-$ shakeflask, open diamonds: $250 \mathrm{~mL}$-shakeflask. 1.2 (middle): viable cell density and viability during bioreactor batch-cultivation. open squares: 2 L-glass vessel, open circles: 20 L-stainless steel reactor. 1.3 (right): specific growth rate $\mu$ of bioreactor cultivation vs. corresponding specific productivity qP. open diamonds: $20 \mathrm{~L}$ - stainless steel reactor, open squares: $2 \mathrm{~L}$-glass vessel

batch cultivation in STR. Other cultivation strategies have been established successfully (incl. chemostat and dialysis-bioreactor) documenting the potential of the AGE1.HN cell line.

\section{Acknowlegments}

The work presented was part of SysLogics (Systems biology of cell culture for biologics), which is funded by German Federal Ministry of Education and Research. Cultivation of $125 \mathrm{~mL}$ shakeflasks and bioreactor tubes were done in Saarbruecken, dialysis cultivation in Hamburg, chemostat-process was done in Magdeburg, while $250 \mathrm{~mL}$ shakeflask, 2 L-glass vessel and $20 \mathrm{~L}$ stainless steel bioreactor-cultivation were performed in Bielefeld.

\section{Author details}

${ }^{1}$ Institute for Cell Culture Technology, University of Bielefeld, Germany. ${ }^{2}$ Max Planck Institute for Dynamics of Complex Technical Systems, Magdeburg, Germany. Institute for Bioprocess and Biosystems Engineering, Hamburg University of Technology, Germany. ${ }^{4}$ Biochemical Engineering Institute, Saarland University, Saarbruecken, Germany. ${ }^{5}$ ProBioGen AG, Berlin, Germany.

Published: 22 November 2011

doi:10.1186/1753-6561-5-S8-P87

Cite this article as: Schräder et al: Characterisation of cultivation of the human cell line AGE1.HN.AAT. BMC Proceedings 2011 5(Suppl 8):P87.

\section{Submit your next manuscript to BioMed Central} and take full advantage of:

- Convenient online submission

- Thorough peer review

- No space constraints or color figure charges

- Immediate publication on acceptance

- Inclusion in PubMed, CAS, Scopus and Google Scholar

- Research which is freely available for redistribution

Submit your manuscript at www.biomedcentral.com/submit 